\title{
Identification and characterization of maize lines resistant to leaf diseases
}

\section{Identificação e caracterização de linhagens de milho resistentes a doenças foliares}

\author{
Kaian Albino Corazza Kaefer ${ }^{1 *}$; Adilson Ricken Schuelter ${ }^{2}$; Ivan Schuster ${ }^{3}$; \\ Jonatas Marcolin ${ }^{1}$; Eliane Cristina Gruszka Vendruscolo ${ }^{4}$
}

\begin{abstract}
Among the maize leaf diseases, white leaf spot, northern leaf blight, gray leaf spot, and southern rust are recognized not only by the potential for grain yield reduction but also by the widespread occurrence in the producing regions of Brazil and the world. The aim of this study was to characterize common maize lines for resistance to white leaf spot, northern leaf blight, gray leaf spot, and southern rust and suggest crosses based on the genetic diversity detected in SNP markers. The experiment was conducted in a randomized block design with three replications in order to characterize 72 maize lines. Genotypic values were predicted using the REML/BLUP procedure. These 72 lines were genotyped with SNP markers using the $650 \mathrm{~K}$ platform (Affymetrix ${ }^{\circledR}$ ) for the assessment of the genetic diversity. Genetic diversity was quantified using the Tocher and UPGMA methods. The existence of genetic variability for disease resistance was detected among maize lines, which made possible to classify them into three large groups (I, II, and III). The maize lines CD 49 and CD50 showed a good performance and can be considered sources of resistance to diseases. Therefore, their use as gene donors in maize breeding programs is recommended. Considering the information of genetic distance together with high heritability for leaf diseases, backcrossing of parent genotypes with different resistance levels, such as those of the lines CD49 x CD69 and CD50 x CD16, may result in new gene combinations, as they are divergent and meet good performances.
\end{abstract}

Key words: Genetic resistance. Pantoea ananatis. Exserohilum turcicum. Cercospora zeae-maydis. Puccinia polysora.

\section{Resumo}

Dentre as doenças foliares do milho, a mancha branca, a helmintosporiose, a cercosporiose e a ferrugem polissora são reconhecidamente importantes, não somente pelo potencial de redução de rendimento de grãos, mas também pela ocorrência generalizada nas regiões produtoras do Brasil e do mundo. $\mathrm{O}$ trabalho teve como objetivo caracterizar linhagens de milho comum para resistência à mancha branca, helmintosporiose, cercosporiose e ferrugem polissora, e sugerir cruzamentos com base na diversidade genética detectada em marcadores SNP. Para a caracterização das 72 linhagens, o experimento foi conduzido no delineamento em blocos casualizados com três repetições. Os valores genotípicos foram

\footnotetext{
1 Discentes, Universidade Estadual do Oeste do Paraná, UNIOESTE, Marechal Cândido Rondon, PR, Brasil. E-mail: kaiankaefer@ hotmail.com; jonatas_marcolin@hotmail.com

2 Prof., Faculdade Educacional de Medianeira, UDC MEDIANEIRA, Medianeira, PR, Brasil. E-mail: adilson_schuelter@yahoo. com.br

3 Pesquisador, LongPing High Tech, LP SEMENTES, Cravinhos, SP, Brasil. E-mail: ivanschuster.ivan@gmail.com

4 Prof., Universidade Federal do Paraná, UFPR, Palotina, PR, Brasil. E-mail: vendruscolo@ufpr.br

* Author for correspondence
} 
preditos empregando-se o procedimento REML/BLUP. Para a avaliação da diversidade genética, as 72 linhagens foram genotipadas com marcadores SNP empregando-se a Plataforma 650K (Affymetrix ${ }^{\circledR}$ ). A diversidade genética foi quantificada utilizando-se os métodos de Tocher e UPGMA. Foi possível detectar a existência de variabilidade genética para resistência a doenças entre as linhagens de milho, além de classificá-las em três grandes grupos (I, II e III). As linhagens CD 49 e CD50 apresentaram bom desempenho e podem ser consideradas fontes de resistência às doenças. Desta forma recomendase a utilização dessas linhagens como doadoras de genes em programas de melhoramento de milho. Aliando as informações da distância genética com as altas herdabilidades encontradas para as doenças foliares, o retrocruzamento de genótipos aparentados, com diferentes níveis de resistência, tais como os das linhagens CD49 x CD69 e CD50 x CD16 podem resultar em novas combinações gênicas por serem divergentes e reunirem bons desempenhos.

Palavras-chave: Resistência genética, Pantoea ananatis, Exserohilum turcicum, Cercospora zeamaydis, Puccinia polysora.

\section{Introduction}

In the last two decades, an expressive increase in the frequency of maize diseases was detected, mainly leaf diseases. This increase in the incidence and severity of diseases is highly related to the changes in the maize production system, such as the expansion of the agricultural frontier, expansion of planting periods (season and off-season), adoption of no-tillage system, increased use of irrigation systems, absence of crop rotation, and use of susceptible materials. Thus, these changes in the production system resulted, on the one hand, in an increasing crop productivity, and on the other hand, they were responsible for promoting changes in the population dynamics of pathogens, resulting in the emergence of new problems inherent to the occurrence of diseases (SILVA et al., 2015).

Among maize leaf diseases, white leaf spot (Pantoea ananatis), northern leaf blight (Exserohilum turcicum), gray leaf spot (Cercospora zeae-maydis), and southern rust (Puccinia polysora) are recognized as important both for the potential reduction of grain yield and for the generalized occurrence in the producing regions of Brazil and the world (SILVA et al., 2015). In addition, other problems are reported, such as the inefficiency of fungicides to control the white leaf spot (JULIATTI et al., 2004), the fact that the occurrence of the northern leaf blight predisposes the plant to pathogens that cause stem rot (COTA et al., 2010), stem deterioration and plant lodging caused by the gray leaf spot under high severities (CASELA; FERREIRA, 2003), and the high variability of the southern rust pathogen, which allows a fast adaptation to the resistant materials available in the market (DUDIENAS et al., 2013).

In spite of the means of disease control and the technology available in the agricultural sector, the use of genetically resistant cultivars is the main control measure since it reduces production costs and the risks to the activity and environment through the decrease in the use of agricultural pesticides (VIEIRA et al., 2009a). In this sense, genetic information derived from genetic characterization studies and genetic diversity of germplasm allow guiding the actions of breeding programs, especially in the identification of resistance sources and quantification of the genetic variability of the population, providing essential information to the researches for predicting superior genotypes and crosses that optimize heterosis (CRUZ et al., 2012).

Introduction of resistance in susceptible germplasm is more efficient when based on preliminary studies of the identification of promising parents, estimation of genetic parameters, and determination of gene effects (VIEIRA, 2010). According to studies of genetic inheritance, most leaf diseases are described as monogenic or qualitative, but some of them can be characterized as polygenic or quantitative (OGLIARI et al., 2007).

Different studies have demonstrated the existence of genetic variability regarding resistance 
to white leaf spot, being the additive gene action more important than non-additive effects (GUIMARÃES et al., 2009; VIVEK et al., 2010; NIHEI; FERREIRA, 2012). The additive gene action has also been predominant in most studies of inheritance of resistance to gray leaf spot (DERERA et al., 2008; VIEIRA et al., 2009b; BRITO et al., 2012; BALESTRE et al., 2012) and southern rust (VIVEK et al., 2010; VIEIRA et al., 2011). However, the resistance for northern leaf blight can be controlled by the action of additive and nonadditive effects (OGLIARI et al., 2007; VIEIRA et al., 2009a). Such information is essential to guide and maximize the exploration of genetic variability.

Genetic diversity studies are also essential tools in breeding programs in order to direct with a higher precision the crosses that allow a higher probability of obtaining superior genotypes through the formation of groups (FERNANDES et al., 2015). Among the methods of predictive multivariate analysis, the Tocher and UPGMA methods have been featured by being extensively used in studies of genetic divergence of common maize (PAIXÃO et al., 2008; COIMBRA et al., 2010; ADEYEMO et al., 2011; FERNANDES et al., 2015). These methods allow grouping genotypes with a higher similarity, leading to a homogeneity within each group and a heterogeneity between groups (CARGNELUTTI FILHO et al., 2008).

Therefore, the aim of this study was to characterize common maize lines for resistance to white leaf spot, northern leaf blight, gray leaf spot, and southern rust and suggest crosses based on the genetic diversity detected in SNP markers.

\section{Material and Methods}

The experiments were carried out in the experimental field and in the Laboratory of Biotechnology of COODETEC (Cooperativa Central de Pesquisa Agrícola) located in Cascavel, PR, at the geographical coordinates $24^{\circ} 53^{\prime} 8.54^{\prime \prime} \mathrm{S}$ and $53^{\circ} 32^{\prime} 4.72^{\prime \prime} \mathrm{W}$, with an altitude of $678 \mathrm{~m}$.

\section{Characterization of lines}

Seventy-two COODETEC maize lines were characterized. These lines were denominated CD01 to CD72 and were constituted of different resistance levels to the maize leaf diseases white leaf spot, northern leaf blight, gray leaf spot, and southern rust.

The experiment was carried out under field conditions using a randomized block design with three replications. Each replication was established as an agricultural season, i.e. off-season 2013, 2014, and 2015. The experimental unit consisted of four rows of five meters with 20 plants per row and interrow spacing of $0.76 \mathrm{~m}$. Four rows of a hybrid highly susceptible to leaf diseases were used as a border in order to increase the incidence of diseases in the field. Crop management was carried out according to crop recommendations, except for fungicide application (EMBRAPA, 2010).

Lines were naturally infected in the field and then assessed for leaf lesions in the grain-filling stage (R3), which was performed 32 days after flowering, according to Lopes et al. (2007). The assessment of the severity of the studied diseases was carried out through visual estimations of the leaf area affected by the disease by means of a diagrammatic scale varying from 1 to 6 , as shown in Figure 1.

The grades of white leaf spots, northern leaf blight, gray leaf spot, and southern rust attributed to the lines were submitted to genotypic analysis by the REML/BLUP procedure (RESENDE, 2008).

The genetic parameters were estimated using the known phenotypic value (y) for the prediction of genetic $(\mathrm{GV})$ and genotypic values $(\mathrm{GpV})$, which are unknown random variables (RESENDE, 2008). The phenotypic value can be expressed by $\mathrm{y}=\mu+a$ $+d+e$, where $\mathrm{y}$ is the temporary phenotypic value, $\mu$ is the overall mean, $a$ is the additive effect, $d$ is the dominance effect, $e$ is the environment effect, $\mu+a$ is the additive genetic value, and $\mu+a+d=\mu+g$ is the genotypic value. 
Figure 1. Diagrammatic scale for evaluation of corn leaf diseases.

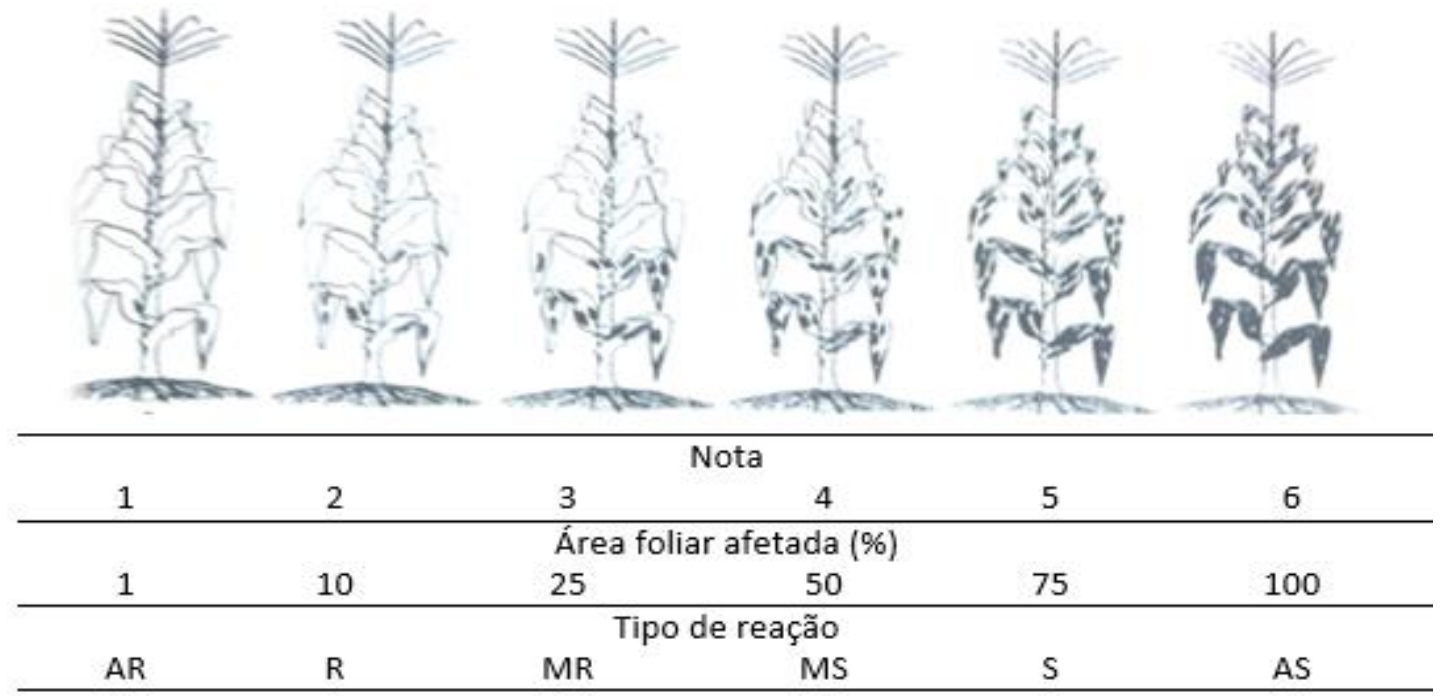

AR - high resistance, R - resistant, MR - medium resistance, MS - medium susceptibility, S - susceptible, AS - high susceptibility. Source: National Maize and Sorghum Research Center (CNPMS) - http://panorama.cnpms.embrapa.br/marcos/avaliacao-dedoencas-do-milho.

The parameters and genotypic values were obtained with the model 21 of the software SELEGEN-REML/BLUP, suitable for selecting genotypes with several replications and observations of means in a single location, according to the model $\mathrm{y}=\mathrm{Xr}+\mathrm{Zg}+\mathrm{e}$, where $\mathrm{y}$ is the vector of data, $\mathrm{r}$ is the vector of the replication effects (assumed as fixed) added to the general mean, $g$ is the vector of the genotypic effects (assumed as random) and e is the vector of errors or residuals (random). Uppercase letters represent the incidence matrices for these effects (RESENDE, 2008).

The genotypic correlation coefficient was estimated by a simple Pearson's correlation analysis from the genotypic values obtained by REML/ BLUP procedure. The significance of the correlation coefficients was assessed by the t-test at 1 and $5 \%$ probability error using the statistical software Genes (CRUZ, 2013).

\section{Analysis of genetic diversity by SNP markers}

Leaf disks of the 72 maize lines were collected in the V5 stage, being duly conditioned in Eppendorf tubes and taken to the Laboratory of Biotechnology of COODETEC to perform the DNA extraction process. The genomic DNA was obtained using the Doyle and Doyle protocol (1990). Samples were quantified and the purity was verified in a spectrophotometer (NanoDrop ${ }^{\circledR}$ 2000-2000c).

Genomic DNA samples were sent to the company Affymetrix (Affymetrix Inc., Santa Clara, CA, USA), which performed genotyping with SNP markers using the $650 \mathrm{~K}$ platform.

For the analysis of results, the calculation of the genetic distance between two populations (I and J) was estimated according to Yao et al. (2007) from the complement of the coefficient of simple coincidence. Based on the distances, a matrix of Dij values was constructed, which gave rise to the genetic dissimilarity matrix.

The genetic diversity between accessions was assessed using the Tocher optimization method and the unweighted pair group method with arithmetic mean or UPGMA method, as suggested by Cruz et al. (2012). The cut-off point in the dendrogram was based on the formula Cut-off point $=$ Mean 
+ (Standard deviation $\times$ cut-off reference value $)$ (CRUZ, 2008). The statistical procedures were carried out by means of the software GENES (CRUZ, 2013).

\section{Results and Discussion}

The study of line characterization showed an accuracy relatively high, i.e. above $86 \%$ (Table $1)$, with an excellent experimental precision since the accuracy measures the correlation between predicted genetic values and observed values (RESENDE, 2008).

Table 1. Predicted genotypic values (VG) with lower (INF) and higher limits (SUP), and genetic parameters for resistance to White leaf spot (WS), northern leaf blight (NB), gray leaf sport (CS) and southern rust (SR) estimated by REML / BLUP (SELEGEN, Model 21) evaluated in common corn germplasm (Cascavel/PR, winter crop 2013, 2014 e 2015).

\begin{tabular}{|c|c|c|c|c|c|c|c|c|c|c|c|c|c|c|}
\hline LINES & WS & NB & CS & SR & LIN. & WS & NB & CS & RS & LIN. & WS & NB & CS & $\mathrm{RS}$ \\
\hline CD01 & 3,42 & 3,81 & 3,60 & 3,59 & CD25 & 3,83 & 2,43 & 3,07 & 2,95 & CD49 & 1,61 & 2,31 & 2,20 & 1,89 \\
\hline $\mathrm{CD} 02$ & 1,46 & 2,25 & 4,82 & 1,91 & CD26 & 2,58 & 2,81 & 4,02 & 1,89 & CD50 & 1,89 & 3,06 & 2,76 & 1,89 \\
\hline $\mathrm{CD} 03$ & 3,42 & 3,06 & 4,44 & 4,36 & $\mathrm{CD} 27$ & 4,67 & 3,06 & 3,60 & 2,53 & CD51 & 3,44 & 3,63 & 4,79 & 1,48 \\
\hline CD04 & 2,81 & 2,75 & 3,07 & 4,46 & CD28 & 1,89 & 2,18 & 3,60 & 1,89 & CD52 & 4,87 & 5,04 & 5,18 & 5,71 \\
\hline CD05 & 4,11 & 4,19 & 4,86 & 2,95 & CD29 & 2,72 & 3,44 & 3,60 & 3,59 & CD53 & 3,42 & 2,68 & 3,60 & 4,86 \\
\hline CD06 & 3,83 & 4,06 & 3,60 & 3,18 & CD30 & 3,00 & 2,18 & 3,60 & 3,59 & CD54 & 4,25 & 3,06 & 4,44 & 4,86 \\
\hline CD07 & 4,67 & 2,18 & 3,60 & 2,53 & CD31 & 2,16 & 2,68 & 5,42 & 1,89 & CD55 & 3,97 & 2,41 & 4,24 & 3,18 \\
\hline CD08 & 3,83 & 2,68 & 5,00 & 2,31 & CD32 & 3,00 & 2,68 & 4,30 & 2,53 & CD56 & 1,33 & 4,25 & 3,60 & 4,86 \\
\hline CD09 & 3,83 & 3,44 & 4,44 & 3,59 & CD33 & 4,59 & 5,30 & 5,18 & 4,01 & CD57 & 1,33 & 3,75 & 3,60 & 4,86 \\
\hline CD10 & 4,67 & 4,19 & 5,42 & 1,89 & CD34 & 2,58 & 3,06 & 5,42 & 5,71 & CD58 & 2,30 & 2,75 & 4,86 & 1,89 \\
\hline CD11 & 4,67 & 4,19 & 5,42 & 1,89 & CD35 & 4,25 & 3,44 & 4,44 & 2,53 & CD59 & 2,30 & 2,41 & 5,42 & 1,89 \\
\hline $\mathrm{CD} 12$ & 2,75 & 3,25 & 2,49 & 1,89 & $\mathrm{CD} 36$ & 3,33 & 3,37 & 4,79 & 5,71 & CD60 & 2,16 & 2,92 & 4,86 & 4,86 \\
\hline CD13 & 1,89 & 2,43 & 5,42 & 2,53 & CD37 & 2,16 & 3,06 & 2,76 & 2,31 & CD61 & 2,23 & 4,25 & 4,82 & 4,46 \\
\hline CD14 & 3,00 & 2,43 & 4,86 & 3,59 & CD38 & 2,58 & 3,06 & 4,02 & 2,53 & CD62 & 1,61 & 2,92 & 5,42 & 4,22 \\
\hline CD15 & 1,61 & 2,31 & 3,60 & 1,89 & CD39 & 3,39 & 3,25 & 4,82 & 3,18 & CD63 & 2,16 & 4,69 & 3,07 & 2,53 \\
\hline CD16 & 4,67 & 4,56 & 4,24 & 4,22 & $\mathrm{CD} 40$ & 2,58 & 2,68 & 3,60 & 1,91 & & 1,61 & 3,81 & 3,60 & 2,53 \\
\hline CD17 & 4,67 & 4,19 & & 3,59 & & 3,42 & 2,18 & & & & 3,42 & 3,25 & 3,60 & 4,65 \\
\hline CD18 & 1,61 & 3,44 & 4,44 & 3,59 & CD42 & 2,58 & 3,44 & 3,60 & 4,22 & CD66 & 2,58 & 3,25 & 3,60 & 4,65 \\
\hline CD19 & 2,58 & 2,68 & 3,07 & 1,89 & CD43 & 2,72 & 3,44 & 4,44 & 1,89 & CD67 & 2,23 & 3,25 & 4,82 & 3,18 \\
\hline CD20 & 4,67 & 4,56 & 3,18 & 3,16 & CD44 & 2,58 & 4,56 & 4,24 & 3,18 & CD68 & 3,39 & 3,25 & 3,66 & 4,46 \\
\hline CD21 & 4,25 & 3,06 & 3,66 & 1,89 & CD45 & 3,39 & 4,25 & 4,82 & 3,18 & CD69 & 5,32 & 4,25 & 5,60 & 5,31 \\
\hline $\mathrm{CD} 22$ & 1,61 & 2,31 & 4,44 & 4,22 & CD46 & 3,00 & 2,68 & 4,44 & 1,89 & CD70 & 2,23 & 3,25 & 3,66 & 3,18 \\
\hline CD23 & 1,90 & 3,13 & 3,63 & 4,87 & CD47 & 3,00 & 4,19 & 5,42 & 4,86 & CD71 & 2,23 & 2,25 & 3,66 & 3,18 \\
\hline $\mathrm{CD} 24$ & 3,00 & 3,06 & 2,76 & 2,53 & CD48 & 3,00 & 2,68 & 3,18 & 2,95 & CD72 & 3,39 & 3,25 & 4,82 & 3,18 \\
\hline Acur. & 0,91 & 0,86 & 0,91 & 0,94 & $\mathrm{Ve}$ & 0,76 & 0,80 & 0,5 & 0,58 & $\mathrm{~h}^{2} \mathrm{~m}$ & 0,83 & 0,75 & 0,83 & 0,89 \\
\hline Ave & 3,02 & 3,25 & 4,14 & 3,24 & $\mathrm{Vp}$ & 2,04 & 1,61 & 1,39 & 2,21 & $\mathrm{CVg} \%$ & 37,49 & 27,6 & 22,7 & 39,4 \\
\hline $\mathrm{Vg}$ & 1,28 & 0,80 & 0,88 & 1,63 & $\mathrm{~h}^{2} \mathrm{~g}$ & 0,62 & 0,50 & 0,63 & 0,73 & $\mathrm{CVe} \%$ & 28,92 & 27,5 & 17,2 & 23,5 \\
\hline
\end{tabular}

Acur = accuracy; Ave = average; $\mathrm{Vp}=$ phenotypic variance; $\mathrm{Vg}=$ genotypic variance; $\mathrm{Ve}=$ residual variance; $\mathrm{h}^{2} \mathrm{~g}=$ genetic heritability in the broad sense; $\mathrm{h}^{2}$ média = average heritability of lineages in the broad sense; $\mathrm{CVg} \%=$ genotype coefficient of variation; $\mathrm{CVe} \%=$ residual coefficient of variation. 
The predicted genotypic values of lines for reaction to leaf diseases ranged from 1.33 to 5.32 (CD56 to CD69) for white leaf spot (WS), 2.18 to 5.30 (CD07 to CD33) for northern leaf blight (NB), 2.2 to 5.6 (CD49 to CD69) for gray leaf spot (GS), 1.48 to 5.71 (CD51 to CD34) for southern rust (SR) (Table 1). These results evidenced the existence of a high genetic variability for the studied traits among the assessed maize lines. In addition, they indicate sources of resistance that can be used to improve the tolerance to white leaf spot (CD02, 13, 15, 18, $22,23,28,49,50,56,57,62$, and 64 ), northern leaf blight (CD07, 28, 30, and 41), gray leaf spot (CD49), and southern rust (CD02, 10, 11, 12, 15, $19,21,26,28,31,40,41,43,46,49,50,51,58$, and 59). Considering the good performance of the lines CD49 and CD50 as sources of resistance, their use as gene donors is suggested in maize breeding programs.

The averages of genotypic values for resistance to the diseases WS, NB, GS, and SR were 3.02, $3.25,4.14$, and 3.24 , respectively (Table 1 ). The genetic constitution of these lines favored the highest contribution to the expression of resistance to leaf diseases, in which WS, GS, and SR presented genotypic variances of $1.28,0.88,1.63$, respectively, since the environment had a low influence, with values of residual variance of $0.76,0.50$, and 0.58 , respectively. For the expression of resistance to northern leaf blight, the genetic constitution had the same contribution as the environmental one $(\mathrm{Vg}=0.8$ and $\mathrm{Ve}=0.8$ ). The high influence of environmental changes on the characteristic of interest can be an aggravating factor in the assessment of lines since it makes it difficult to identify the genotypes when it is based only on the observed phenotype (BESPALHOK et al., 2007).

Heritability is based on the proportion of phenotypic variance under genetic control by estimating the ratio between genetic variation and total variance (BORÉM; MIRANDA, 2013). The average heritability of lines in the broad sense observed for the reaction to the four-leaf diseases was high, i.e. above 75\% (Table 1), showing the possibility of obtaining superior genotypes through simple breeding strategies, for instance, the backcrossing (CRUZ et al., 2012).

There is variability between lines since, among the 616,201 assessed SNP markers, 418,287 markers were polymorphic and with a high resolution. In addition, the highest genetic distance recorded was 0.3186 (CD01 x CD17) and the shortest distance was 0.0015 (CD18 x CD56), with a mean distance of 0.11771 . These values of distance between lines were similar and considered of a low magnitude by Aguiar et al. (2008), Adeyemo et al. (2011), and Fernandes et al. (2015) because the number of markers were relatively low $(99,75$, and 44 , respectively) when compared to the performed study (418,287 markers).

The genetic variability found among lines made the assessment of the genetic divergence by means of molecular markers an essential tool since it suggested possible crosses by group formation (FERNANDES et al., 2015). The Tocher grouping method allowed the combination of lines into three large groups with their respective subgroups (Figure 2). Group I was composed of most of the maize lines, covering $91.6 \%$ of the assessed lines. In relation to the subgroups, subgroup I presented $77 \%$ of the 72 lines, followed by subgroups II, III, IV, IX, and X, which consisted of two lines each. On the other hand, the subgroups V, VI, VII, VIII, $\mathrm{XI}$, and XII were represented in an isolated way, respectively, by CD51, CD46, CD69, CD27, CD34, and CD17.

For cluster analysis by the UPGMA hierarchical method, the arbitrary cut-off level was established in the relative size of the merger (distances) levels in the dendrogram, being defined the cut-off point in the distance of 0.30 . Therefore, as in the Tocher grouping, the UPGMA cluster analysis, which was obtained based on the genetic dissimilarity matrix, showed the division of lines into three large groups (Figure 2). 
Figure 2. Dendrogram of the grouping by the UPGMA method of 72 corn lines, based on the distance of the simple coincidence complement obtained through molecular markers SNP (Cascavel / PR, 2016).

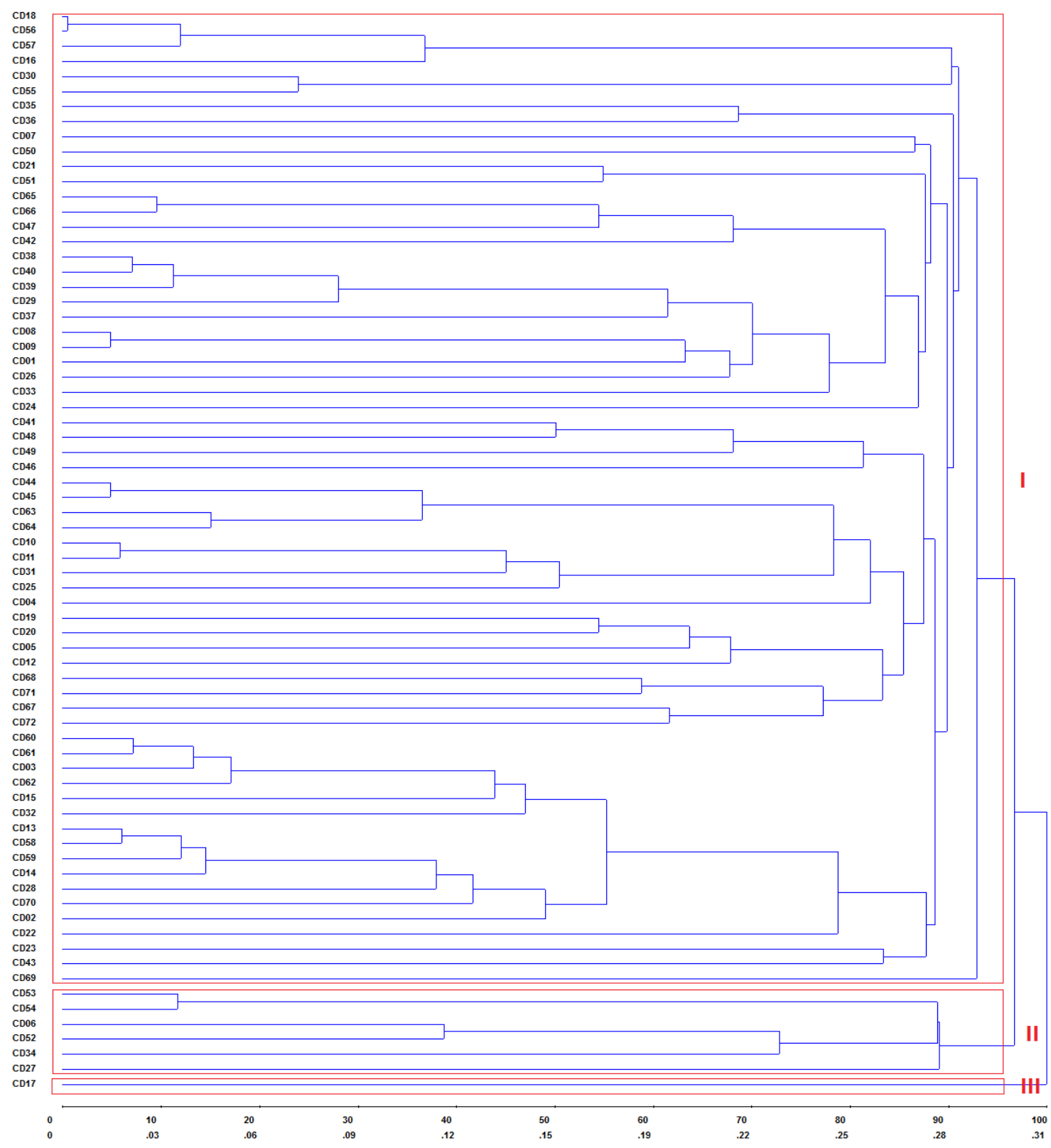

Among the methods of predictive multivariate analysis, the Tocher and UPGMA methods has stood out since they are extensively used in studies of genetic divergence combined with the productive potential of common maize (PAIXÃO et al., 2008; COIMBRA et al., 2010; ADEYEMO et al., 2011; FERNANDES et al., 2015). In addition, these methods allow grouping genotypes with a higher similarity in order to reach a consistency within each group and heterogeneity between groups (CARGNELUTTI FILHO et al., 2008). Thus, they provide essential information for choosing parents, allowing a higher probability of success in later crossings (ROTILI et al., 2012).

The fact that both diversity analyses have presented the highest concentration of lines in group I is entirely related to the used genotypes, which 
are the main elite lines of the company's breeding program and may not necessarily be covering all the genetic variability of the heterotic groups since there are genotypes with a higher genetic diversity when compared to those studied, but they do not present a good agronomic performance. Thus, there is, in fact, a high genetic diversity among the studied lines, but there is an imbalance in the distribution between groups because some lines participate in many crosses with genotypes of other groups, resulting in the generation of commercial hybrids.

Combining the genetic distance information with the high heritability found for leaf diseases, it is recommended crossing parent materials with different resistance levels, i.e. materials from the same group (Group I, Figure 2) by using the backcrossing method. In this sense, possible backcrosses can be suggested, such as those of the lines CD49 (GD) x CD69 (GR) and CD50 (GD) $x$ CD16 (GR) in order to raise resistance to the studied pathogens and recover as soon as possible the genome of the recurrent parent.

In order to facilitate the selection of promising genotypes, the estimation of genotypic correlation coefficients between traits of interest is used since it involves an association of heritable nature (CRUZ et al., 2012). In this study, a highly significant $(p<0.01)$ and positive genotypic correlation of 0.38 was observed for the simultaneous selection of resistant genotypes for WS $x$ NB and 0.33 for NB $x$ SR (Table 2). In addition, a significant $(p<0.05)$ and positive genotypic correlation of 0.24 was observed for NB x GS. Similarly, Arnhold et al. (2008) studied the selection for resistance to leaf diseases in S1 families of popcorn maize and verified genotypic correlations for the white leaf spot $\mathrm{x}$ common rust of 0.24 , northern leaf blight $x$ common rust of 0.35 , and white leaf spot $x$ northern leaf blight of -0.59 .

Table 2. The values of the genetic correlation coefficients obtained for resistance to white leaf spot (WS), northern leaf blight (NB), gray leaf sport (CS) and southern rust (SR), estimated by Pearson's simple correlation (Cascavel/PR, winter crop 2016).

\begin{tabular}{ccccc}
\hline & WS & NB & CS & RS \\
\hline WS & - & & & \\
NB & $0,38^{* *}$ & - & & \\
CS & $0,21^{\mathrm{ns}}$ & $0,24^{*}$ & - & - \\
RS & $0,10^{\mathrm{ns}}$ & $0,33^{* *}$ & $0,21^{\mathrm{ns}}$ & - \\
\hline
\end{tabular}

** Significant at $1 \%$ probability; $*$ Significant at $5 \%$; ${ }^{\text {ns }}$ not significant.

The results show the perspectives of future studies with the exploration of genetic variability among the assessed elite lines aiming at obtaining simple hybrids with a higher resistance to the main maize leaf diseases or even the formation of future populations for the development of new lines.

\section{Conclusion}

There is a genetic variability among maize lines and it is possible to classify them into three large groups, allowing their crossing to obtain resistant lines.

Considering the good performance of the lines CD49 and CD50 as sources of resistance to the studied diseases, their use as gene donors in maize breeding programs is recommended.

Considering the information of genetic distance together with high heritability for leaf diseases, backcrossing of parent genotypes with different resistance levels, such as those of the lines CD $49 x$ CD69 and CD50 x CD16, may result in new gene 
combinations, as they are divergent and meet good performances.

\section{Acknowledgments}

To the Cooperativa Central de Pesquisa Agrícola (COODETEC) for the facilities to carry out this experiment and to CAPES for the granting the master's degree scholarship to the first author.

\section{References}

ADEYEMO, O.; MENKIR, A.; MELAKU, G.; OMIDIJI, O. Genetic diversity assessment and relationship among tropical-yellow endosperm maize inbred lines using SSR markers. Maydica, v. 56, n. 1, p. 17-23, 2011.

AGUIAR, C. G.; SCHUSTER, I.; AMARAL JUNIOR, A. T.; SCAPIM, C. A.; VIEIRA, E. S. Heterotic groups in tropical maize germplasm by test crosses and simple sequence repeat markers. Genetic and Molecular Research, Ribeirão Preto, v. 7, n. 7, p. 1233-1244, 2008.

ARNHOLD, E. Seleção para resistência a doenças foliares em famílias S1 de milho pipoca. Revista Ceres, Viçosa, v. 55, n. 2, p. 89-93, 2008.

BALESTRE, M.; VON PINHO, R. G.; BRITO, A. H. Bayesian inference to study genetic control of resistance to gray leaf spot in maize. Genetics and Molecular Research, Ribeirão Preto, v. 1, n. 1, p. 17-29, 2012.

BESPALHOK, J. C.; GUERRA, E. P.; OLIVEIRA, R. Melhoramento de plantas. Curitiba: UFPR, 2007. 8 p. Disponível em: <http:www.bespa.agrarias.ufpr.br/ conteudo $>$. Acesso em: 25 fev. 2017.

BORÉM, A.; MIRANDA, G. V. Melhoramento de plantas. 5. ed. Viçosa, MG: UFV, 2013. 523 p.

BRITO, A. H.; DAVIDE, L. M. C.; VON PINHO, R. G.; CARVALHO, R. P.; REIS, M. C. Genetic control of resistance to gray leaf spot of maize in tropical germplasm. Corn Breeding and Applied Biotecnology, Viçosa, v. 12, n. 2, p. 145-150, 2012.

CARGNELUTTI FILHO, A.; RIBEIRO, N. D.; REIS, C. P.; SOUZA, J. R.; JOST, E. Comparação de métodos de agrupamento para o estudo da divergência genética em cultivares de feijão. Ciência Rural, Santa Maria, v. 38, n. 8, p. 2138-2145, 2008.

CASELA, C. R.; FERREIRA, A. S. A cercosporiose na cultura do milho. Sete Lagoas: EMBRAPA-CNPMS, 2003. 5 p. (Circular técnica, 24). Disponível em: $<$ http:// docsagencia.cnptia.embrapa.br/milho/ circul24.pdf $>$. Acesso em: 15 jan. 2017.

COIMBRA, R. R.; MIRANDA, G. V.; CRUZ, C. D.; MELO, A. V.; ECKERT, F. R. Caracterização e divergência genética de populações de milho resgatadas do sudeste de Minas Gerais. Revista Ciência Agronômica, Fortaleza, v. 41, n. 1, p. 159-166, 2010.

COTA, L. V.; SILVA, D. D.; COSTA, R. V.; PARREIRA, D. F. Recomendação para o controle químico da Helmintosporiose do sorgo (Exserohilum turcicum). Sete Lagoas: EMBRAPA Milho e Sorgo, 2010. 7 p. (Circular técnica, 149). Disponível em: <https://ainfo.cnptia. embrapa.br/digital/bitstream/item/26831/1/Circ-149. pdf $>$. Acesso em: 15 jan. 2017.

CRUZ, C. D. GENES - a software package for analysis in experimental statistics and quantitative genetics. Acta Scientiarum, Maringá, v. 35, n. 3, p. 271-276, 2013.

CRUZ, C. D. Programa Genes: diversidade genética. Viçosa, MG: Editora UFV, 2008. v. 1, 278 p.

CRUZ, C. D.; REGAZZI, A. J.; CARNEIRO, P. C. S. Modelos biométricos aplicados ao melhoramento genético. 4. ed. Viçosa, MG: Editora UFV, 2012. v. 2, $514 \mathrm{p}$.

DERERA, J.; TONGOONA, P.; KEVIN, V. P.; VIVEK, B.; LAING, M. D.; RIJ, N. C. V. Gene action controlling gray leaf spot resistance in Southern African maize germplasm. Crop Science, Madison, v. 48, n. 1, p. 93-98, 2008.

DOYLE, J. J.; DOYLE, J. L. Isolation of plant DNA from fresh tissue. Focus, v. 12, p. 13-15, 1990.

DUDIENAS, C.; FANTIN, G. M.; DUARTE, A. P.; TICELLI, M.; BÁRBARO, I. M.; FREITAS, R. S.; LEÃO, C. P. L.; CAZENTINI FILHO, G.; BOLONHEZI, D.; PÂNTANO, A. P. Severidade de ferrugem polissora em cultivares de milho e seu efeito na produtividade. Summa Phytopathologica, Botucatu, v. 39, p. 16-23, 2013.

EMPRESA BRASILEIRA DE PESQUISA AGROPECUÁRIA - EMBRAPA. Cultivo do milho. Sete Lagoas: EMBRAPA, 2010. (Manual Técnico).

FERNANDES, E. H.; SCHUSTER, I.; SCAPIM, C. A.; VIEIRA, E. S. N.; COAN, M. M. D. Genetic diversity in elite inbred lines of maize and its association with heterosis. Genetics and Molecular Research, Viçosa, v. 14, n. 2, p. 6509-6517, 2015.

GUIMARÃES, P. S.; PATERNIANI, M. E. A. G. Z.; DUDIENAS, C.; LÜDERS, R. R.; GALLO, P. B. Capacidade combinatória para resistência à mancha branca em linhagens endogâmicas de milho. Summa 
Phytopathologica, Piracicaba, v. 35, n. 4, p. 282-287, 2009.

JULIATTI, F. C.; APPELT, C. C. N. S.; BRITO, C. H.; GOMES, L. S.; BRANDÃO, A. M.; HAMAWAKI, O. T.; MELO, B. Controle da feosféria, ferrugem comum e cercosporiose pelo uso da resistência genética, fungicidas e épocas de aplicação na cultura do milho. Bioscence Journal, Uberlândia, v. 20, n. 3, p. 45-54, 2004.

LOPES, M. T. G.; LOPES, R.; BRUNELLI, K. R.; SILVA, H. P. da; MATIELLO, R. R.; CAMARGO, L. E. A. Controle genético da resistência à mancha-de-Phaeosphaeria em milho. Ciência Rural, Santa Maria, v. 37, n. 3, p. 605-611, 2007.

NIHEI, T. H.; FERREIRA, J. M. Análise dialélica de linhagens de milho com ênfase na resistência a doenças foliares. Pesquisa Agropecuária Brasileira, Brasília, v. 47, n. 3, p. 369-377, 2012.

OGLIARI, J. B.; GUIMARÃES, M. A.; GIRALDI, I. O.; CARMARGO, L. E. A. New resistance genes in the Zea mays: Exserohilum turcicum pathosystem. Genetics and Molecular Biology, São Paulo, v. 28, n. 3, p. 435-439, 2007.

PAIXÃO, S. L.; CAVALCANTE, M.; FERREIRA, P. V.; MADALENA, J. A. S.; PEREIRA, R. G. Divergência genética e avaliação de populações de milho em diferentes ambientes no Estado de Alagoas. Revista Caatinga, Mossoró, v. 21, n. 4, p. 191-195, 2008.

RESENDE, M. D. V. Genômica quantitativa e seleção no melhoramento de plantas perenes e animais. Colombo: EMBRAPA Florestas, 2008. 330 p.

ROTILI, E. A.; CANCELlIER, L. P.; DOTTO, M. A.; PELUZIO, J. M.; CARVALHO, E. V. Divergência genética em genótipos de milho, no estado do Tocantins. Ciência Agronômica, Fortaleza, v. 43, n. 3, p. 516-521, 2012.

SILVA, D. D.; COTA, L. V.; COSTA, R. V. Doenças. In: SILVA, D. D.; COTA, L. V.; COSTA, R. V.
Cultivo de milho. 9. ed. Sete Lagoas: EMBRAPA Milho e Sorgo, 2015. 8 p. (Sistemas de produção, 1). Disponível em: <https://www.spo.cnptia.embrapa.br/ conteudo?p_p_id=conteudoportlet_WAR_sistemasde producaolf6_1ga1ceportlet\&p_p_lifecycle $=0 \& p \_p \_$ state $=$ normal\&p_p_mode $=$ view $\&$ p_p_col_ id $=$ column1\&p_p_col_count $=1 \& p$ _r_p_76293187_si stemaProducaoId=7905\&p_r_p_996514994_ topicoId=866>. Acesso em: 15 jan. 2017.

VIEIRA, R. A. Melhoramento genético da resistência à helmintosporiose comum, cercosporiose e ferrugem polissora em milho-pipoca. 2010. Dissertação (Mestrado em Genética e Melhoramento) - Universidade Estadual de Maringá, Maringá.

VIEIRA, R. A.; SCAPIM, C. A.; TESSMANN, D. J.; HATA, F. T. Diallel analysis of leaf disease resistance in inbred Brazilian popcorn cultivars. Genetics and Molecular Research, Viçosa, v. 8, n. 4, p. 1427-1436, 2009b.

VIEIRA, R.A.; SCAPIM, C.A.; TESSMANN, D.J.; HATA, F.T. Diallel analysis of yield, popping expansion and Southern rust resistance in popcorn lines. Revista Ciência Agronômica, Fortaleza, v. 42, n. 3, p. 774-780, 2011.

VIEIRA, R. A.; TESSMANN, D. J.; HATA, F. T.; SOUTO, E. R.; MESQUINI, R. M. Resistência de híbridos de milho-pipoca a Exserohilum turcicum, agente causal da helmintosporiose do milho. Scientia Agraria, Curitiba, v. 10, n. 5, p. 391-395, 2009a.

VIVEK, B.; ODONGO, O.; NJUGUNA, J.; IMANYWOHA, J.; BIGIRWA, G.; DIALLO, A.; PIXLEY, K. Diallel analysis of grain yield and resistance to seven diseases of African maize (Zea Mays L.) inbred lines. Euphytica, v. 172, p. 329-340, 2010.

YAO, Q.; YANG, K.; PAN, G.; RONG, T. Genetic diversity of maize (Zea mays L.) landraces from Southwest China based on SSR data. Journal of Genetics and Genomics, v. 34, n. 9, p. 851-860, 2007. 